\title{
UNDERSTANDING RELIGIOUS VIOLENCE IN INDONESIA Theological, Structural and Cultural Analyses ${ }^{1}$
}

\author{
Ahmad Salehudin \\ UIN Sunan Kalijaga, Yogyakarta - Indonesia
}

\begin{abstract}
Lately Indonesia is facing a lot of tremendous experience about religious violence. Indonesian Islam which is previously assumed as peaceful religion is suddenly changing to be frightening religion. The destruction in some places such as Bali Bombing, JW Marriot Bombing, and Sampang riot in some places Islam is the trigger of religious violence. This paper discusses the repetition of religious violence in Indonesia especially after New Order era. The writer argues that religious violence in Indonesia is as natural disaster, historical process in human evolution and as close experience that presenting and relating to human history. It may be caused by political condition and the response to economic injustice. In doing so, it is kind of social acceleration toward the process of change and also being a factor of the emergence of new agenda. This is because every disaster, including religious violence, requires an adjustment and a new formulation of the functions that have been damaged.
\end{abstract}

Keywords: Religious violence, natural disaster, theology.

\section{Introduction}

In October 2002, many people were shocked when all mass media such as print media, electronic media, and online media reported a suicide bombing in Bali Island that caused more than 187 people dead and 400's were wounded. This tremendous phenomenon was then followed by same phenomena that made many people, be it Muslims

\footnotetext{
${ }^{1}$ The earlier version of this paper was presented at The $12^{\text {th }}$ Annual International Conference on Islamic Studies (AICIS), held by the Ministry of Religious Affairs and the State Institute of Islamic Studies (IAIN) Sunan Ampel, Surabaya, 5-8 November 2012.
} 
or non-Muslims, Indonesians and foreigners, aware that the pattern of Islamic religiosity in Indonesia is changing. Indonesian Islam which is usually considered as friendly and tolerant, then, suddenly showing cruel face and frightening, not only for non-Muslims but also for Muslims themselves.

Historically, the changing pattern of Islam in Indonesia recently appeared in the end of the New Order and to be clearer after the New Order fell down in 1998. Post-1998, the violence cases on behalf of religion increased both in their intensities and ways. The bomb exploded everywhere and every time from the crowded centres, hotels, to the worship places. Some of the cases such as the suicide Bali bombings at Legian street, Bali (October 22, 2002) which led to hundreds of people dead, a suicide bombing at the Ritz Charlton Hotel and JW Marriot Hotel in Jakarta (2009) which killed dozens of people, a book bomb in the JIL and News Office $68 \mathrm{H}$, Utan Kayu street, East Jakarta (March 2011) which caused the police hands broken, and suicide bombing of Muhammad Sharif in the mosque of the Cirebon police station on Friday (04/15/2011) and so on. There are also many other forms of terrorism, ranging from more intimidation, vandalism of religious place, arson of the religious member house and to murder up.

Actually, the terror action is not only carried out by terrorist groups, but also by the state in order to deracinate a group which is identified as terrorist group. For example how the television broadcasting raid terrorist in Temanggung, Central Java. The television illustrated it as a horrible moment like war movies. Also when the fully armed Detachment 88 troops siege a house suspected to be harbouring terrorists, strafed it with bullets and thrown it with the hands bombs. Those views that usually aired repeatedly by television and became the main dish of print media for some days bring on the pain and frightening terror not only to the directly victims but also to indirectly victims such as the television viewers as well as readers of mass media.

Actually, suicide bombings were not previously "known" in Indonesia as ways to make the dream comes true. The pattern of "struggle" of Islamic groups in Indonesia using a suicide bombing is adopted from the struggle patterns of religious groups abroad ${ }^{2}$ as an impact of globalization era that provides the homogenization of social

2 Ahmad Salehudin, Satu Dusun Tiga Masjid: Tarik-menarik antar aliran Islam dalam Masyarakat Jawa (Yogyakarta: Pilar Media, 2007). 
action patterns. It is a matter of fact that globalization provides much opportunity for the people to learn more and copy the idea as well as the way to make it comes true. Therefore this condition provides a vast opportunity for the Islamic groups in Indonesia to learn from other people or groups across the world how to achieve their goal effectively. In addition from those series of terrible events we also know that there are imitations (copying) or Talibanization ${ }^{3}$ in conducting religious violence in Indonesia.

However, as previously explained religious violence in Indonesia is not new phenomena. It is easy to find the evidence in the history of religion in Indonesia. The failure to avoid, prevent and overcome the religious violence is because of the assumption that religious violence is new phenomena.

\section{Religious Violence: A Theoretical Frame Work}

The phenomenon of religious violence is old phenomenon. Therefore, it is not difficult to understand why such horrible phenomena repeat. In order to have thorough understanding, religious violence will be elaborated as a close experience and subjected as a natural disaster.

First, religious violence is as close experience. It means that that religious violence always presents, happens and relates to the human history both directly experienced by the subject people themselves and by the other people in many places and times. However, in fact religious violence is always assumed to be new phenomenon, as something that never happened before. As a result, the conception and response to the religious violence are not based on knowledge and collective consciousness. It just looks like fire-fighters ${ }^{4}$ douse the flames after a fire. The fact that religious violence is very close to the human experience should raise awareness, not only among social

\footnotetext{
${ }^{3}$ Talibanization was used by Beelver Singh to identify new phenomena of religious terror in Southeast Asia, especially Indonesia. According to Singh, Talibanization is the process of involves the adoption of Islamist doctrines, ideologies, and values that are largely militant in character, which for some groups includes the adoption of violencesuicide bombing-to achieve their goals.

${ }^{4}$ Assumes the religious violence such as fire does not mean putting the role of fire in a less important position, because it is based on the role behind its creation, the fire department is supposed to work when there is a fire. This is of course different from the religious violence that could have been prevented and/or minimized to know and understand the signs, then find a solution to solve it.
} 
scientists who are studying and observing the social phenomena and their changes intensively but also religio-social scientists, clergies, and policy makers to examine the properties, causes, consequences of it as well as the responses and overall impact. Base on this awareness, it will be found a theoretical framework of the repeatability of religious violence, especially those that occur in Indonesia. This theoretical framework is very important and able to be used by stakeholder. As Murphy said in Irwan Abdullah, "to manipulating, domesticating, remoulding, reconstructing and harvesting..."5.

Second, religious violence can be categorized as natural disaster. It means that religious violence does not happen suddenly or it can be said that natural disaster is God will. Religious violence-like natural disaster-has a certain characteristic that can be explained or studied. Eruption for example has certain characteristic such as the increase of water temperature around the mountain, the exodus of animals, etc. By understanding the characteristic of natural disaster people will have chance to anticipate or avoid the natural disaster. Because religious violence also has certain characteristic that can be studied therefore religious violence can be defined as natural disaster.

Based on the characteristic of religious violence, stakeholders have a lot of chance to make holistic and productive policy to avoid, eliminate the effects of religious violence. Religious violenceborrowing Jan Smith word__..... are part of nature, have happened in the past and will happen again..."6. Furthermore, if religious violence has been to be collective consciousness, the anticipated program should be integrated into the life and social policy.

\section{Repeated Religious Violence}

In the history of religious violence in Indonesia, it is found out that religious violence in Indonesia has become a daily part the religious life. Interestingly, it is also found out that religious violence was a ritual of violence accruing since long time before Indonesia got independence until today, where democracy has always glorified. By

\footnotetext{
${ }^{5}$ Irwan Abdullah, Dialektika Natur, Kultur, Struktur: Analisis Konteks, Proses, dan ranah dalam Konstruksi Bencana (Pidato Pengukuhan Guru Besar Antropologi pada Fakultas Ilmu Budaya Universitas Gadjah Mada, 2006.), p. 7.

"Jan Smith, “Are Catastrophe is Nature Ever Evil?” in WB Dress (ed.), Is nature Ever Evil? Religion, Science and V alue (London and New York: Routledge Taylor and Francis Group, 2003), p. 97.
} 
doing a flashback on some of religious violence, since the early development of Islam in Indonesia until today, it will be known that religious violence in Indonesia is close experience that always repeats. ${ }^{7}$

The first case is the execution of Syech Siti Jenar in the 1500's. Syech Siti Jenar had experienced religious violence. He has been executed by the walisongo (the legendary Nine Saints), because he had different understanding in Islamic teachings with the mainstream Muslims. According to walisongo, Syech Siti Jenar's Islamic understanding was dangerous because potentially destructive the creed of people who just knew Islam. This phenomenon is similar with what happened in the case of Irsyad Manji (May 9, 2012), as well as the student of Sekolah Pasca Sarjana UIN Sunan Kalijaga Yogyakarta who was banned from the school because the members of some Islamic group are afraid to his thought.

In the 1800s, religious violence occurred in West Sumatra which is called as the Padri war. It was a war against the Dutch colonialism or usually called independence war. It was a battle between Tuanku Imam Bonjol with the Dutch. However, if tracing the origin of the Padri war, it would be found that the main cause of Padri war was not the aggression of the Dutch, but the resistance of the traditional leader of Minangkabau namely Sultan Pagar Ruyung and indigenous stakeholders in Minangkabau remaining adamant to run the custom, against Islamist who want to apply the Wahabi Islam. Wahabi Islam tended to be unfriendly to the local customs and culture and wanted to replace it with Islamic culture. This was the cause of religious violence in West Sumatra in the 1800s.

The phenomenon of religious violence also occurred after the independence of Indonesia. It can be seen in short story entitled "The Sky Getting Cloudy" (Langit Makin Mendung) the work of Ki Panji Kusmin that was published in the Sastra magazine August 8, 1968. Its content was deemed insulting the sanctity of Islam. The magazine then received wide criticisms from various parties especially from the Muslims. As a result, North Sumatra High Court banned Sastra

\footnotetext{
7 Some cases of religious violence that I have to say here is a subjective choice to simply give the plot and narrative immediacy and reproducibility of the violence in the name of religion. Similarly, the disclosure of cases of violence, mostly religious-related to Islam, intended as a reflection for me personally as a Muslim and academics who feel called to participate to contribute ideas for ongoing efforts to eliminate religious violence.
} 
magazine. Later, Sastra magazine ${ }^{8}$ was banned. HB Jassin, the original name of Ki Panji Kusmin, the editor of the magazine, was brought to

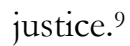

The next example is Tabloid Monitor case in 1990. Monitor which was the best-selling tabloid owned by Kelompok Kompas-Gramedia (KKG) distributed the questionnaire about the most admired figures according to the readers on Monday, October 15, 1990. The poll result showed that the Prophet Muhammad was in the eleventh rank, one level below Arswendo Atmowiloto, the chief editor of Monitor which ranks tenth. The publication of poll results then sparked anger among Muslims. Monitor was not only deemed insulting the Prophet Muhammad but also assumed reviving the sentiment of race, religion, and ethnicity. The protest was waged intensively by the Council of Indonesian Ulama (MUI) and organizations representing Islam such as the Muslim Students Association (HMI) and the Youth of Muhammadiyah. ${ }^{10}$

Since the protest against the Monitor was getting more intense, the government through the Information Minister, Harmoko, on Tuesday, October 23, 1990 pulled out the Monitor publishing license. Then the branch of Indonesian Journalists Association in Jakarta issued a letter which stopped the membership of Arswendo Atmowiloto from Indonesian Journalists Association (PWI) and revoke the recommendation for the post of editor in chief. The culmination of the event is when Arswendo Atmowiloto was tried and sentenced for five years in prison. At that time KH. Abdurrahman Wahid (Gus Dur) was the only one who had different thought on the case.

\footnotetext{
${ }^{8}$ In addition to banning the Sastra magazine and the editor faced to the court, another thing that interesting to discuss is the clarification on charges of insulting Islam by $\mathrm{Ki}$ Pandji Kusmin through editorial of Harian Kami, on October 22, 1968. In such clarification, Ki Pandji Kusmin repeals short stories and never thought existed. It is the clarification of Ki Pandji Kusmin, "Sebermula sekali bukan maksud saya mengbina agama Islam. Tujuan sebenarnya adalah semata-mata hasrat pribadi saya mengadakan komunikasi langsung dengan Tuban, Nabi Mubammad Saw, surga, dll. Di samping menertawakan kebodohan di masa rezim Soekarno. Tapi rupanya saya telah gagal, salah menuangkannya ke dalam bentuk cerpen. Alhasil mendapat tanggapan di kalangan umat Islam sebagai penghinaan terbadap agama Islam."

9 Rumadi, "Delik Penodaan Agama dan Kehidupan Beragama dalam RUU KUHP" Paper presented at Annual Conference of Islamic Studies (ACIS), Bandung, 2006.

10 Ibid.
} 
In 1996, a massive religious riot occurred in Situbondo. This case originated from Saleh's statement that Allah is unusual creatures and $\mathrm{KH}$ As'ad Syamsul Arifin, the founder of the Islamic boarding school "Salafiyah Syafi'iyah" Situbondo and the NU highly respected ulama died imperfectly (in the Madures language called mate takacer). As a result, Saleh was arrested by the police and brought to justice in Situbondo. In the day when the charges was read on October 10, 1996, most of the mass who was not satisfied with the prosecution and would like Saleh to be sentenced to death penalty began to throw stones at the courthouse and burnt it, burnt the cars which were parked in front of the courthouse, several churches, Christian schools, and shops.

In 2004 religious violence was experienced by Mangapin Sibuea, the sect leader of Pondok Nabi in Bandung. Mangapin Sibuea was sentenced two years in prison on charges of violating Article 156a KUHP about hostility, abuse or desecration of a religion followed in Indonesia by the District Court Bale Endah, Bandung, West Java. Mangapin experienced violence due to his deviant teachings.

The next is the case of the Rus'an's article entitled “Islam agama yang gagal' (Islam is the failed religion) that was published by the Radar Sulteng on Thursday, June 23, 2005. In his article, Rus'an, a lecturer of the University of Muhammadiyah Palu and secretary of the DPC PAN Palu, was questioning the religion that did not affect so much to their adherents. According to him, the religions in Indonesia had failed affecting their followers at all. He quoted the words of Karl Marx that "religion is the opium of the people". Religion is spiritual liquor. Religion is seen as the cause of oppression, class exploitation and further the cause of the emergence of non-productive imaginations. He even stated that the public was more like watching soap operas then listen to the advice of religious leaders who are full of hatred. Even more painful for Muslim leaders in Palu were his statements that blamed religion and not persons associated with the corruption. His statements on the last paragraph of his book namely "...By looking at the reality of what happened as described above, we have to decide whether religion still has meaning for human life in the present or not? If the answer is no, it means that religion has failed..." This statements triggered anger among the masses.

In 2005, violence in the name of religion was also experienced by the Yayasan Kanker dan Narkoba Cahaya Alam (YKNCA) at 
Kerampilan village, district Besuk Probolinggo led by Ardhi Hussein. On Friday, May 27, 2005, YKNCA was invaded and destroyed by thousands of the masses. Destruction and invasion of the foundation linked to the controversial content of the book "Menembus Gelap Menuju Terang 2" written by Ardhi Hussein and judged heretical by the MUI Probolinggo. Various media reported that about 3000 people invaded and partially threw stones to YKNCA until the houses were destroyed. In this case Ardhi Hussein was jailed for five years on charges of blasphemy.

The next case was bilingual prayer of Yusman Roy, the leader of "the Pondok I'tikaf Ngaji Lelaku", in Malang, East Java. It was also a portrait of religious violence. Yusman Roy and his followers is praying in bilingual (Arabic-Indonesia), a prayer that was rather unusual. As it was not common, the practice was considered wrong and "misleading". Some religious communities like Majlis Ulama Indonesia (MUI), Nahdlatul Ulama (NU) and Muhammadiyah considered the practice of prayer against Prophet Muhammad. He was eventually tried and jailed 2 years. Muhammad Yusman Roy came under attack from many quarters and barely any defence argument satisfactory. He is not a cleric, kiyai, academics, or people who grow and thrive in strictly religious traditions. He was not so concerned with the methodology of jurists. He just wants to teach the community how to understand what Muslim should read in the prayer, so that prayer is not only a ritual but also has atsar (remaining) to the actor. He then created a formula prayers in two languages, namely Arabic followed by the Indonesian language. If we see it profoundly and clearly, then we will know that what Yusman Roy did in Malang was a "low voice" to counter the hegemony of Arabism. Although Yusman Roy was lost in argument, and sent to prison, but his spirit to assert the Indonesian identity (Indonesianiziton) of in the heart of strong Arabism commendable. ${ }^{11}$

Religious violence was also experienced by Eden Communities in 2005. Victim of this case is Lia "Eden" Aminuddin. She was sentenced two years in prison on charges of defamation of religion. The incident began on Wednesday, December 28, 2005, when the Lia Aminuddin's house located at Jalan Mahoni 30, Bungur, Jakarta Pusat, was surrounded by a lot of people. They were protesting the spread of Lia's teaching, which had been considered heresy by the Council of

11 Rumadi, "Delik Penodaan Agama". 
Indonesian Ulama. As a result, Lia "Eden" Aminuddin had been jailed for several years on charges of violating Article 156 and 157 KUHP about blasphemy and sedition.

On February 7, 2011, religious violence was experienced by members of Ahmadiyah in Cikeusik, Banten. Violence against Ahmadiyah members in Cikeusik was carried out by Islamic groups who believe that Islamic Ahmadiyah heretical because considered Mirza Ghulam Ahmad as a prophet. Ahmadiyah belief is in contrast with the belief of the majority of Indonesian Muslims; the Prophet Muhammad is the last prophet, and if there is an opinion that there is prophet after Prophet Muhammad SAW, then of course that opinion is misguided. In the Cikeusik tragedies there were at least three people died, dozens were injured, some houses of Ahmadiyah followers destroyed and burned down by masses. What happened to members of Ahmadiyah in Cikeusik also spread to several areas not just physically but also psychologically. Head of East Java and West Java Province responds to the events of Cikeusik by issuing legislation freezing Ahmadiyah. Moreover, Pandam Siliwangi held Sajadah operation to "Islamize" Ahmadiyah members.

Not so long after the Cikeusik tragedy, religious violence also occurred in Temanggung, Central Java Province. The riots that occurred on February, 8 makes a lot of researchers begin to turn their views to the Temanggung. As known, in two years Temanggung became the centre of national news because terrorist suspects had been shot dead in the area. Temanggung riot began with a flyer circulated by Anthony Richmond Bawengan that was considered insulting Islam. As a result of his actions, Anthony Richmond Bawengan was arrested and faced to court. Apparently the five-year sentence verdict sparked mass discontent since the morning crowded courtroom. Dissatisfaction was infuriated mob. The mass became violent, destroyed the courthouse, motor vehicles were burned, and several churches was burn down.

In addition to the phenomenon of religious violence experienced by minority groups as mentioned earlier, the post-1998 the Islamic minority groups, especially those affiliated and/or influenced by transnational Islamic groups, began to dare to fight against the mainstream religious groups and countries with reviving the spirit of jihad. According to Martha Crenshaw small organization resort to violence to compensate for what they lack in number. Below I will so you how Islamic minority group dare to do "religious violence" in God's name. 
On 15 April 1999, for example, a bomb exploded at Plaza Hayam Wuruk, West Jakarta. The perpetrators were Naiman, Edi Taufik, Suhendi, and Edi Rohadi, members of Angkatan Mujahidin Islam Nusantara (AMIN) led by Eddy Ranto. He was also accused of involvement in bomb explosions at the Istiqlal Mosque, Jakarta, on 19 April 1999. Eddy Ranto was also suspected of masterminding the robbery of Bank BCA Taman Sari, Jakarta and the bombing of the kiosks in HayamWuruk, Jakarta.

Bomb detonated in August 2000 at the residence of the Philippine ambassador to Indonesia, at the Jalan Imam Bonjol, Jakarta. The bomb blast killed two domestic staff residence as well as dozens of others injured seriously. The perpetrators were Abdul Jabar, Fatur Rahman Al-Ghozi and Usman alias Edi Setiono. On October 19, 2003, the Central Jakarta District Court sentenced Ahmad bin Abdul Jabar Kandai for 20 years in prison. In addition to the embassy bombings at the residence of the Philippines ambassador, he was also guilty of taking part in the number of church bombings in Jakarta, such as the Menteng Anglican Church, Jakarta Pusat, and the Ecumenical Church at Jalan Angkasa Halim Perdana Kusuma, Jakarta.

On Christmas Eve 2000, bombs exploded again in various places in Indonesia, including Jakarta, Sukabumi, Bandung, Mojokerto, Mataram, PematangSiantar, Medan, Batam and Pekanbaru, which resulted in dozens of people dead, hundreds more were injured and dozens of cars damaged. In July 2001, bombs exploded at the Church of Santa Anna, PondokBambu, Jakarta. The explosion injured dozens of people.

Bombing case that was quite shocking occurred on October 12, 2002. Three bomb blasts rocked Bali. The first and second explosion rocked at the area in JalanLegian, Kuta, while the other explosion occurred near the U.S. consulate in Denpasar. The explosion in JalanLegian, resulting in at least 187 killed and 400 other's wounds. The explosion also caused severe damage in a radius of 100 meters from the centre of the explosion.

Bali bombing was the first suicide bombing in Indonesia made a lot of people aware that religious terrorist groups began to grow and develop quite rapidly in Indonesia. Indonesia that is known as a country for friendly and tolerant Muslims seemed to disappear and changed its face into the harsh Islam. Although some of the Bali bombers had been sentenced to death, cases of suicide bombings 
continue to emerge, such the one at the JW Marriott hotel, Jakarta, on August 5, 2003 that killed 13 people, injuring 74 people and destroyed 22 cars; Bali Bombing two on October 1, 2005 at RAJA's Bar and Restaurant, Kuta Square, Kuta Beach area and in Nyoman Café Jimbaran, which killed 22 people and wounded 102, and another one at the JW Marriott and Ritz-Carlton, Jakarta, on July 17, 2009. After the collapse of the New Order the phenomena of suicide bombings increase (see CRCS annual report "Kehidupan Beragama di Indonesia in 2008-2011).

Based on the cases explained above, it shows that there are at least four forms of religious violence, i.e. violence against other religions; violence against "the same religion"; religious violence using nonreligious institutions (the state), and non-religious violence in the area of religion. The fourth form of religious violence in the region-nonreligious violence in the area of religion-in recent years, particularly in the post New Order, increase massively, such as sweeping undertaken by religious organizations to areas of prostitution and liquor, as well as actions that are considered to deviate from the rules of religion. The increasing violence of this fourth type is apart from strengthening of formalization of religion, as well as the ineffectiveness of state institutions to deal with social ills.

It is also found that there is a pattern change of religious violence in Indonesia before and after 1998. Prior to 1998, religious violence was often committed by groups of the majority against the minority whether conducted directly or used the hands of the state. Whereas in the post-1998, religious violence is mostly done by minority persons and/or groups against the others who are considered infidels. In addition, the ways used are also more sophisticated. If the methods used before 1998 were traditional means (destruction and intimidation), in the post-1998 the method used is more sophisticated and frightening.

\section{Understanding the Reasons of Religious Violence}

Religion is a commodity that looks reassuring and calming in one side but frightening in the other side. That true religion is the individual response understood as an absolute reality, it is often reduced when dealing with the collective experience of undergoing process of standardization and institutionalization in the form of freezing religion. 
Cultural responses associated with the construction of meaning over the truths of religion in every human life are important to be understood. Construction of meaning of religious violence here is loaded with the interests because the sound of various parties involved in determining the form of discourse-which later became the opinion-is the result of matches involving multiple actors. This is because the religious motives of action, whether leading to violence and or peace, are always associated with complex existential statement, particularly with respect to the relation of God-servant.

From the religious violence cases mentioned above, and/or recent religious violence phenomena as experienced by Irsyad Mandji in UGM Yogyakarta, violence perpetrated should not necessarily be seen as "persecution" as performed by the robbers to the victims, but it has also a justification of religion-based truth claims. Based on the comments made by the leaders of religious groups, it is clear that the violence is the answer of God calling. Thus, the religious violence has the sense of sacred as the manifestation of obedience to God. Suicide bombings carried out by a group of Bali bombers, for example, was regarded as praiseworthy and noble.

Actually not only the perpetrators of the violence that underlies his attitude as a response to the God calling, the victims of religious violence also do the same action. Fortitude and firmness of the victims to maintain and carry conviction is also an expression of obedience and submission to God. Therefore, no wonder if they get violence both physically and psychologically into their beliefs, they remain firm to endure with his teachings even though they often make the changes to the current mainstream as several members of the Ahmadiyah did who ultimately has vowed to return to mainstream Islam and leave religious understanding that they hold for decades. It is rather strange if the faith they profess for decades suddenly be stripped away. By this phenomenon, it can be built an understanding that there are several possibilities that will happen either on the perpetrators and victims of violence. The post-religious violence Victims will probably survive and become more firmly to their beliefs because they think that violence is experienced as a test of their faith, as the Eden community and most of the Ahmadiyah members have done. Because of that religious 
violence-using Mark Juergenmeyer words-is product of internal logic not of random or crazy thinking. ${ }^{12}$

Probably, they will leave their faith and move to mainstreams religious thought as seen from some members of the Ahmadiyah pledge that was broadcast live by the electronic media. Although based on religious studies known that such a pattern of repentance, especially involving the structure of the country as was done by the Siliwangi military command in West Java through Sajadah operations tend to justify that the "displacement" happened not on the basis of belief in consciousness but fear. This pattern actually will never resolve the conflict but simply put conflict under the surface.

Religious violence can also be seen as historical process in human evolution. Disaster, i.e. religious violence, as a process of "social change", thus, becomes an important factor in changing the structure of social life, because every disaster requires an adjustment and a new formulation of the functions that have been damaged. ${ }^{13}$ The changes that occur may be accelerating the process of change and also being a factor of the emergence of a new agenda. In the case of the Ahmadiyah in Cikeusik, Banten, for example, it is known that such a humanitarian catastrophe has been the reason of the East Java and West Java Governor to make a regulation disbanding the Ahmadiyah religious activities.

It also becomes the reason for the mass organizations that had been instigating violence against the Ahmadiyah to further strengthen the pressure on the government to immediately disband Ahmadiyah. In another context, the case would also be starting point to develop new agenda how to restructure to prevent Indonesia from the threats of strong religious formalization. According to Mark Juergensmeyer, ${ }^{14}$ strategy implies a degree of calculation and expectation of accomplishing a clear objective that does not jibe with a dramatic display of power. In the Bali bombing and other suicide bombing, or specific religious violence, for example, the purpose may be does not to achieve a strategic goal but to make a symbolic statement.

\footnotetext{
12 Mark Jurgensmeyer, Terror in the Mind of God: The Global Rise of Religious Violence (Berkeley, Los Angeles, London: University of California Press, 2000), p. 123.

13 Abdullah. Dialektika Natur, Kultur, Struktur, p. 10

${ }^{14}$ Jurgensmeyer, Terror in the Mind of God, p. 123.
} 
If religious violence is just seen as a factor of doctrine and social change, it means that there is a neglecting in looking at the humans being able to anticipate the potential factors that emerge. This example can be seen from the case of Ahmadiyah. Why have Ahmadiyah members in Banten West Java always been the object of violence but not Ahmadiyah in Yogyakarta. Meanwhile, Ahmadiyah members in Yogyakarta can coexist peacefully and productively with their fellow Muslims. What happened in Yogyakarta can certainly be used as a basis for analysis that the differences in the understanding of religion should not be a trigger of violence. Jusuf Kalla, for example thinks that the religious violence that occurred is solely a result of economic, political, and social injustice. Therefore, according to him, religious violence can be prevented by ensuring economic, political and religious justice.

\section{Response to Religious Violence}

Based on the explanation above, it can be said that there are three bases of analysis that can be used to understand the religious violence in Indonesia, namely: the doctrinal dimension of religion to see that violence, both in the view of the actor and the victim, a call of their faith; the dimension of historical process in human evolution that positioned religious violence as part human "need", and structural problem dimensions where injustice is positioned as the basis for the analysis of the causes of religious violence. By understanding the third reason the regulation can be made either based on religious perspective or state one to construct anti-religious violent attitude.

First, stakeholders (include state apparatus and religious leader) should be aware that religious plurality is natural law. It is believed that our religious understanding as the most correct understanding is a reasonable attitude, but it must also be sustained by the awareness that others may have the same attitude. By growing this attitude, one would not get caught up in religious absolutism. Djohan Effendi, as quoted by Greg Barton, maintains that as a relative creature, human understanding and knowledge may not be able to reach and capture religion as the truth of a doctrine accurately and thoroughly. Therefore, the understanding of religion is clearly not the religion itself and 
therefore there is no reason to blame the absolute and a priori sense and understanding of others. ${ }^{15}$

The emergence of absolutism attitude towards the understanding of religious doctrine is due to lack of awareness of the limitations of human beings on the one hand, and awareness of the plurality on the other hand. Both of these attitudes will bring up the attitude of tolerance for differences in the understanding of religious doctrines. According to KH. Abdurrahman Wahid, ${ }^{16}$ believers need to have an openness to discover and seek truth from anywhere.

Second, the differences in religious understanding should not end in violence. According to Irwan Abdullah, ${ }^{17}$ the birth of a disaster depends on the susceptibility or vulnerability of individuals, groups, neighbourhoods, and institutions. It also seems to trigger the emergence of religious violence. In other words, religious violence occurs because individuals, groups, neighbourhoods, and institutions have the vulnerability in expressing their religious teachings. It is clear now why differences in understanding religious texts have different effect; it became a trigger of religious violence in one place but not in other places. In Yogyakarta, for example, members of the Ahmadiyah can live peacefully side by side with other relatives, particularly other Muslims, but not in West Java and Banten.

Third, religious violence is religious critique. Religious violence is a momentum to make corrections fundamentally to the religious expressions, and to release religion from the interests covering and trapping it. In the religious history we often see how religion is used by a group of people to satisfy his desire for power so that religion is loss of his divinity messages. Banning Irsyad Mandji to discuss is clear evidence of how religion is often hijacked by the interests.

Fourth, we need to realize that religious violence is not something happens suddenly and it is not inevitable, but it is an event that is always repeated. Religious violence, in its history, is an integral part of religious life. Therefore, a holistic review of religious violence will help us know and understand the signs of events. Religious violence does

\footnotetext{
15 Greg Barton, Gagasan Islam Liberal di Indonesia: Pemikiran Neo-Modernisme Nurcholish Madjid, Djohan Effeni, Ahmad Wahib dan Abdurrahman Wabid (Jakarta: Paramadina, 1999), p. 239.

16 Abdurrahman Wahid, Muslim di Tengah Pergumulan (Jakarta: Lappenas, 1981), p. 3.

17 Abdullah. Dialektika Natur, Kultur, Struktur.
} 
not have to drain energy, breaking down social structures, and endanger the life of the nation. This situation can be created if the religious violence with all its terrible consequences to be collective knowledge of the religious community.

The question is why religious violence is always repeated? Many factors are the cause, among others: (a) religious violence is still regarded as something happens suddenly and not be circumvented. As a result, we forget to understand the signs and predict the emergence of religious violence, (b) we are no longer able to read the signs, so it is not able to make predictions of the possibility of religious violence; (c) there are those who deliberately use religious violence to archive their interests.

\section{Conclusion}

Based on the description above, it can be concluded that religious violence has multidimensional aspects, so that it requires the necessary efforts to genuinely understand it both in terms of external diversity or internal complexity. By looking at the internal and external dimensions, religious violence is a recurring disaster. Therefore, historical understanding is necessary in order to understand the character of religious violence and perform preventive measures to avoid and/or minimize the effects.

In terms of the context, it must be realised that religious violence is not an incidental event. As a context, it gives perspective and definition about the code of conduct that need to be adhered collectively in the form of action and policy formulation. ${ }^{18}$ By seeing it as a context, the trap of normality will be avoided, so that itis possible to make policies to prevent religious violence.

Religious violence can also be used as a big mirror (kacabenggala) of diversity, so that with it then we can construct and develop a new paradigm of how to understand and practice religion without violence. However it must be understood that religious violence will lose the prophetic value of religion in conducting human liberation from suffering. []

18 Ibid. 


\section{Bibliography}

\section{Books and Articles}

Abdullah, Irwan. Berpihak Pada Manusia: Paradigma Nasional Pembangunan Indonesia Baru. Yogyakarta: TICI-PustakaPelajar, 2010.

-. Dialektika Natur, Kultur, Struktur: Analisis Konteks, Proses, dan ranah dalam Konstruksi Bencana. Pidato Pengukuhan Jabatan Guru Besar Antropologi pada Fakultas Ilmu Budaya Universitas Gadjah Mada, 2006.

Andriyanto, Heru, "Ahmadi Victim of Cikeusik Attack Jailed for 6 Months," The Jakarta Globe, 15 August 2011, www.thejakartaglobe.com/news/ahmadi-victim-of-cikeusik-attack-jailed-for-6months/459531

Barton, Greg. Gagasan Islam Liberal di Indonesia: Pemikiran NeoModernisme Nurcholish Madjid, Djoban Effendi, Abmad Wabib dan Abdurrabman Wabid. Jakarta: Paramadina, 1999.

CRCS, Laporan Tahunan Kehidupan Beragama tahun 2008, 2009, 2010, and 2011.

El Fadl, Khaled Abou. Speaking in God's Name. Oxford: Oneworld, 2003.

El-Anshary, Waleed and David K. Linnan. Muslim and Christian Understanding: Theory and Application of A Common World. New York: Palgrave Macmillan, 2000.

Hamid, Abdul, "The Kiai in Banten: Shifting Roles in Changing Times," in Ota Atsushi, Okamoto Masaaki, and Ahmad Suaedy (eds.), Islam in Contention: Retbinking Islam and State in Indonesia, Jakarta: Wahid Institute, Center for Southeast Asian studies (CSEAS) and Center for Asia-Pacific Area Studies (CAPAS), 2010.

Hassan, Ibrahim. Sejarah dan Kebudayaan Islam. Yogyakarta: Kota Kembang, 1989.

Hidayat, Komaruddin and Ahmad Gaus AF (eds). Passing Over: Melintasi Batas Agama. Jakarta: Gramedia Pustaka Utama, 1998.

Husein, ED. The Islamist. London: Penguin Book, 2007. 
Idahram, Syaikh. Sejarah Berdarah Sekte Salafi Wababi: Mereka Membunuh Semunya, Termasuk Para Ulama. Yogyakarta: Pustaka Pesantren, 2011.

Jurgensmeyer, Mark. Terror in the Mind of God: The Global Rise of Religious Violence. Berkeley, Los Angeles, London: University of California Press, 2000.

Meijer, Roel (ed.). Global Salafism: Islam New Religious Movement. London: Husrt \& Company, 2009.

Rumadi. "Delik Penodaan Agama dan Kehidupan Beragama dalam RUU KUHP" paper presented at Annual Conference on Islamic Studies (ACIS) Bandung, 2006.

Salehudin, Ahmad. Satu Dusun Tiga Masjid: Tarik-menarik antar aliran Islam dalam Masyarakat Jawa. Yogyakarta: Pilar Media, 2007.

Smith, Jan. “Are Catastrophe is Nature Ever Evil?.” WB Dress (ed.) Is nature Ever Evil? Religion, Science and Value. London and New York: Routledge Taylor and Francis Group, 2003).

Tamara, M Nasirand Elza Pelda Taher (eds). Agama dan Dialog Antar Peradaban. Jakarta: Yayasan Paramadina, 1996.

Wahid, Abdurrahman. Muslim di Tengah Pergumulan. Jakarta: Lappenas, 1981. 